\title{
The Role of Africa Union to Dissolve Boko Haram Threat through Coordination
}

\section{Arinaldo Habib Pratama}

Master Program Student in Defense Management Study at Universitas Pertahanan arinaldopratama@gmail.com

\begin{abstract}
Abstrak
Benua Afrika saat ini memiliki ancaman bersenjata yang bernama Boko Haram. Dibentuk pada tahun 2002, gerakan ini menjadi perhatian dunia pada tahun 2014 karena aksi mereka menculik 278 orang anak perempuan di kota Chibok, Nigeria dan menginspirasi munculnya tagar \#BringBackOurGirls. Gerakan ini menganut ideologi Khawarij yang secara tegas ingin menegakkan hukum syariah secara menyeluruh di Nigeria, negara gerakan tersebut beroperasi. Artikel ini akan menjelaskan bagaimana regionalisme, melalui Uni Afrika, berupaya menghentikan ancaman dari Boko Haram dan menghentikan upaya mereka dari mempersenjatai diri sendiri. Penelitian akan dilakukan dengan pendekatan kualitatif, melalui studi pustaka. Hasil penelitian yang bisa ditemukan adalah koordinasi negara-negara Afrika melalui Uni Afrika menghasilkan dua jenis upaya, yakni hard power berupa kontingen militer negara-negara Uni Afrika dan soft power melalui berbagai pertemuan.
\end{abstract}

Kata Kunci : Boko Haram, Regionalisme, Africa Union, Coordination, Hard Power, Soft Power

\section{Introduction}

The rise of Boko Haram, an armed group in Nigerian, in 2014 started by abduction of girls student in Chibok, Borno state, Nigeria. But, what most people doesn't know is Boko Haram actually already started their insurgency in 2002. At that time, a riot broke up in a city called Maiduguri because bunch of youth rejecting the city government as corrupt and asking any citizen that still live in the city to implementing hijra or moving together with them, to a village called Kanama, near the border with the Niger to set up a separatist community run on hard-line Islamic Principles. The movement soon to be acknowledged by Muhammad Yusuf, a member of Borno State Sharia, a state body that implement sharia law in Borno state as part of federal government in Nigeria. Yusuf and other member then proceed to built mosque, large farm, religious police, and then founded their own religious based government ${ }^{1}$. The name's Boko Haram movement is taken from Yusuf's intention to distance Nigeria from western ideologue and education into jihadist ideology :

"These European educated Muslims returned home only to confuse other Muslims, claiming that democracy is compatible with Islam, while Jihad should only be for self control...we are for jihad and

\footnotetext{
${ }^{1}$ Lucky E. Asuelime and Ojechenemi J. David (2015), Boko Haram : The Socio-economic Drivers, Springer, New York, pg. 66-68
} 
our jihad is to put an end to democracy, to western education and western civilization. The Jihad is intended to make us (Muslims) return to the original state of Islam ${ }^{2,}$

The sect strongly rejects the secular authority and pursued the Islamization of the Nigerian state, for a Sharia governed system. This purpose is inspired by the Jihadist war, conducted by Usman Dan Fodio between 1804 and 1808, which makes him able to create Sokoto Caliphate and unite Hausa, biggest ethnic group in Nigeria. Inspired by Ibn Taymiyya teaching to revolt against inept and corrupt state, Boko Haram aimed to liberate northern state of Nigeria that already affected by weak sharia implemented by the state but incapable to prevent corruption such as Yobe, Borno, Adamawa, Kano, Kaduna, and Bauchi. The rise of the movement start at 2007, when Yusuf and his movement initiated the killing of Sheikh Jaa'far Mahmoud Adam, a prominent cleric, and also Kano governor at that time. Sheikh Ja'fat criticize the group for it's hardline ideology ${ }^{3}$.

Their members consist of jobless Nigerians, multitude of Muslim graduates that unable to secure job, retired Nigerian soldiers, and war refugee from Chad. The dwindling economic situation able to attract large number of followers, that unable to afford the basic necessities in live, with various benefit such as welfare package, sponsorship while doing religion education, and robber. Aghedo and Osumah (2012) noted that Boko Haram membership "largely relates to the depth of of feeling about socieeconomic injustice, marginalization and human security"4.

The group's major target include the security outfit of the Nigerian government such as army and police, Christian minorities in the north and central regions of Nigeria, and the Muslim political and religious elites. Suicide bomb, Vehicle-Borne Improvised Explosive Device (VBIED), or even attacking their enemies with machetes, club and small arms, become norms of Boko Haram's method $^{5}$.

Since the threat of Boko Haram could spread into Nigeria's neighboured states, the role of Africa Union as form of regionalism is needed. Africa Union's Right of Intervention are regulated under Constitutive act of Africa Union. Africa Union allowed to dismantle the effort of "Unconstitutional Changes of Government", which listed as follows:

- Military coup d'etat against a democratically elected Government

- Intervention by mercenaries to replace a democratically elected Government

- Replacement of democratically elected Governments by armed dissidents groups and rebel movements; and

- The refusal by an incumbent government to relinquish power to the winning party after free, fair and regular elections ${ }^{6}$.

This Right of Intervention then manifested into African Peace and Security Architectures (APSA). APSA is built around structures, objectives, principleas and values, as well as decision-making processes relating to the prevention management and resolution of crises and conflicts, post conflict reconstructions, and development in the continent. The main pillar of the APSA is the Peace and

\footnotetext{
${ }^{2}$ Jacob Zenn, Atta Barkindo, and Nicholas A Heras (2013), The Ideological Evolution of Boko Haram in Nigeria, The Rusi Journal, United Kingdom, pg. 50

${ }^{3}$ Andrew Walker (2012), What is Boko Haram ?, United States Institute of Peace, pg. 3-4

${ }^{4}$ Jacob Zenn, Atta Barkindo, and Nicholas A Heras (2013), op.cit, hal. 73

${ }^{5}$ Ibid, pg. 74-76.

${ }^{6}$ Isiaka A. Badmus (2015), The Africa Union's Role in Peacekeeping : Building on Lessons Learned from Security Operations, Palgrave Macmillan, London, pg. 79
} 
Security Council (PSC), which is supported, in the discharge of its mandate, by various structures, namely: the Commission, the Panel of the Wise, the Continental Early Warning System (CEWS), the African Standby Force (ASF) and the Peace Fund.

The Commission is carrying on the compliance regarding to prevention of conflict by the member states, through data and information gathering that will be put into Observation and Monitoring Centre. The Panel of the Wise, officially inaugurated on December 2017, is acted as advisory body with African perspective that put primacy on wisdom, goodwill and the abilities of elders. The Peace Fund, the principle source of finance for the APSA, is the backbone of AU peace and security activities. The final aspect of APSA is African Standby Force, which become the spearhead of stabilisation effort in Nigeria by regional effort. The very concept of Africa Standby Force is rapid deployment for a multiplicity of peace support operations that may include preventive deployment, peacekeeping, peace building, post conflict disarmament, demobilisation, re-integration and humanitarian assistance ${ }^{7}$.

The concept that would be used in this journal are regionalism and coordination. Regionalism in regional organization, according to Joseph Nye, based on formal agreements among governments, possesing diplomatic forums, and assisted by an associated international bureaucracy. In this sense, the term of regional organization is narrower than the concept of a regional system which can be defined as a regular pattern of interation among independent political units in a region. In other words, the concept of regional "system" includes a wider range of behaviour than does the concept of regional organization. The use of an organization requires conscious policy choices. Systems, on the other hand, tend to be taken as fundamental givens of the of the situation ${ }^{8}$.

According to Malone and Crowston, coordination is the act of managing interdependencies between activities. Coordination activities is related to resources and how much is enough to solving the task. Coordination as activity consist of identifying what resources are required by the task, identifying what resources are available, choosing a set of proper resources, and assigning the resource. Identfying necessary resource means the assigner may need to know what kind of resources are available to be able to characterize the task requirement along the same dimension. Identifying available resources is to understand how many objective could be solved with current resource. Assigning the resources means every resources would be have different task ${ }^{9}$.

\section{Finding and Arguments}

To encounter threat from Boko Haram, Africa Union allows the forming of MNJTF which consist of military personnel from Benin, Chad, Cameroon and Nigeria. According to the AU Communiqué of the 469th PSC meeting;

"The MNJTF is an offensive and stabilisation mechanism with the objective of combating Boko Haram and other groups labelled as terrorists operating around the Lake Chad Basin. Its establishment under its current structure was determined by the LCBC heads of state and government during the Extraordinary Summit of the LCBC member states and Benin in Niamey, Niger on 7

\footnotetext{
${ }^{7}$ Ibid, pg. 92-98.

${ }^{8}$ Joseph S. Nye, Jr, Peace in Parts : Integration and Conflict in Regional Organization (Boston, Mass.1971), pg. 15

9 Jaroslav Kral (2007), Introduction to Coordination Concept, Human Resources Management and Ergonomics, University of Zilina, Slovakia, pg.5
} 
October 2014. On 25 November 2014, the African Union's (AU) Peace and Security Council (PSC) fully endorsed its activation ${ }^{10}$.

The lack of resource become reason of why MNJTF become in active before 2012, or when the activities of the terrorist group Boko Haram became a serious regional threat to the security and stability of this sub region. Lake Chad Basin Commision (LCBC), branch of AU that consist of neighbouring states that living near Lake Chad, decide to :

"Urgently take all necessary measures for the revitalization of the Multinational Joint Tasks Force of the Lake Chad Basin including Cameroon, Niger, Nigeria, Chad and the Central African Republic. Niger will organize as soon as possible a meeting bringing together the defense ministers and armies chiefs of staff (CBLT 2012). ${ }^{11}$ ",

According to the declaration of the heads of state of the LCBC in 2012: "Each member state participates in the MNJTF with at least one equipped battalion. The command becomes rotating starting with the Federal Republic of Nigeria for a period of 6 months". For the LCBC, the need to fulfil this mission implied the availability of a force of 8700 soldiers whose activities would be extended around the Lake Chad with headquarters in N'Djamena, Chad. The MNJTF had a term of one year to ensure peace and security in the Lake Chad Basin in order to guarantee the free movement of goods, people and socio-economic development ${ }^{12}$.

The Nigerian Head of State Muhammadu Buhari instructed that the sum of \$21 million (N4.2 billion) be released to the MNJTF in June 2015. That sum of money was to enable the MNJTF to prosecute the war against Boko Haram effectively. Additionally, Nigeria had promised to donate $\$ 100$ million as part of the much-needed funds for the MNJTF to carry out their task. The president further requested that Nigeria should be allowed to take control of the command of the MNJTF because Nigeria was the main theatre of the war with Boko Haram and the war was very important to Nigeria.45 The regional continent representatives from the neighbouring countries (Cameroon, Chad, Benin, and Niger) also contributed 8700 military, police and civilian troops as their quota in $\mathrm{MNJTF}^{13}$.

But, there are many constraint that would halt the coordination effort of MNJTF. First, Nigeria commitment to contain Boko Haram threat although most of the attack happened in their territory. This is affected by relations between Nigeria and other countries that joining the LCBC. For example, Nigeria can't really comfortable to cooperate with Cameroon because land dispute called 'Bakassi crisis'. Bakassi is peninsula covered by mangrove that lies in Cross River that separated the two countries. This dispute leading to some military encounters between the two countries, as a result of which several lives were lost. In 1994, Cameroon approached the International Court of Justice (ICJ) with the plea of taking over the ownership of the oil-rich peninsula and some islands in Lake Chad. The country got a favourable judgment. The next dispute that happened between Nigeria and other state member of LCBC is some portion of Lake Chad between Nigeria and Chad. Chad always

\footnotetext{
${ }^{10}$ William Assanvo, Jeannine Ella A Abatan and Wendyam Aristide Sawago (2016), Assesing the Multinational Joint Task Force Against Boko Haram, Institute for Security Studies, Cape Town, pg. 6

${ }^{11} \mathrm{Ibid}, \mathrm{pg} .7$

${ }^{12}$ Ellysee Martin Atangana (2018), The underlying reasons for the emerging dynamic of regional security cooperation against Boko Haram, Africa Review, Routledge, pg. 6

${ }^{13}$ Dauda Hairiya (2017), The Role of the Multinational Joint Task Force in Fighting Against Boko Haram in Africa, University of Ghana, pg.28
} 
accusing Nigeria to be safe haven (in Sambisa River Reserve to be exact) of bandit that involve in illicit arms trafficking and banditry ${ }^{14}$.

All of this made it difficult for Nigeria to approach both Cameroon and Chad for support at the inception of the Boko Haram crisis. Chad too played a bystander role as the Boko Haram crisis escalated: pretending to be unaware of how the insurgents were using their countries as safe-havens against Nigeria. In December 2011, the government of President Goodluck Jonathan invoked Section 305(1) of the 1999 Constitution to shut Nigeria's borders with all its immediate neighbours except Benin Republic. In 2012, Nigeria's land borders with Cameroon, Chad and Niger were once again closed, based on the allegation that Boko Haram members were using these countries as safe-havens and the launching pad for their operations. There was another closure of Nigeria's borders with Cameroon, Niger and Chad in May $2013^{15}$.

Another problem is regarding to Nigeria's commitment to conduct their armies against Boko Haram if the attacks happen in one of LCBC's member states. The realities doesn't always suitable with the ideal practice. At 2015, Nigeria commited to put around 3.750 troops from total of 11.150 troops of MNJTF. But, an attack from Boko Haram to Nigeria's military base in Niger prove the commitment doesn't always being followed with capability. One such was the Boko Haram attack on 3 June 2016 on the town of Bosso, Niger. Although this part of Niger is within the operational sphere of the MNJTF - which has a base in the city of Diffa, Nigeria - and Nigeria had pledged to provide nearly 1000 soldiers, the attack was so violent that it seemed doubtful that there had actually been any deployment from Nigeria's military. It also raised questions about the effectiveness of Niger's security apparatus. The attack took place within the context of a deteriorating security situation in the south of Niger. Since the beginning of 2016 this part of the country has seen over 40 attacks ${ }^{16}$.

The last challenge that the researcher able to find is lack of funding and commitment, which could change from the initial intention. Jeffrey Feltman, United Nations Under Secretary-General for Political Affairs, said in 2016, explains the problem of funding in MNJTF operation :

"MNJTF's main challenge remains a severe lack of funding. The 1February African Union donor conference aimed to mobilize $\$ 750$ million, of which only $\$ 250$ million was pledged; even less was disbursed. The success of MNJTF operations also depends on timely and actionable intelligence as well as specialized counter-terrorism skills and equipment, given the evolving tactics of Boko Haram $^{17}$.

During 2015-2016, there is some kind of vagueness regarding numbers of troop each countries able to contributed in MNJTF. The first meeting of LCBC regarding to MNJTF happened at Januari 2015 which agreed to deploy as many as 7.500 military personnel. This number was later shifted to 8700 during the meeting of experts in Yaoundé on 5-7 February 2015, and then to 10000 on 3 March 2015 during the 480th meeting of the PSC. In August 2015 the full component of national contingents announced following the meeting of the chiefs of staff of the LCBC countries and Benin raised the

\footnotetext{
${ }^{14}$ Isaac Olawale Albert (2017), Rethinking the Functionality of the Multinational Joint Task Force in Managing the Boko Haram Crisis in the Lake Chad Basin, Africa Development, Senegal, pg.128

${ }^{15}$ Ibid, pg. 129

${ }^{16}$ William Assanvo, Jeannine Ella A Abatan and Wendyam Aristide Sawago (2016), op.cit, pg. 10

${ }^{17}$ Usman A. Tar and Adejoh Sunday (2017), Military Alliance and Counter-Terrorism in Sub-Saharan Africa : The Multi-National Joint Task Force in Perspective, Covenant University Journal of Politics and International Affair, pg. 9
} 
MNJTF's numbers to nearly 11150 personnel: 3750 from Nigeria, 3000 from Chad, 2650 from Cameroon, 1000 from Niger and 750 from Benin. During the second Regional Security Summit in Abuja on 14 May 2016, Buhari announced a total number of 8500 personnel. The most visible change come from Benin that previously contributing as many 750 personnel, to only 200 personnel due to financial reason ${ }^{18}$.

The Africa Union role to solve this problem is to become 'fund broker' between MNJTF and international communities and nation outside Africa Union. As the result, The United States of America, on its part, supported the creation of the MNJTF and strongly partnered with the members of the MNJTF to fight against Boko Haram. To this end, the US provided intelligence, advisers, training, logistical support and equipment. In May 2014, the U.S Department of Defence sent 12 troops to Nigeria to train 650 Nigerian ranger battalions for combat operations that were presumably free of human rights violations. At the request of the Nigerian government, the U.S deployed drones and surveillance aircraft concentrated on finding the Chibok girls. They also provided informationsharing and supported programmes that provide positive alternatives to communities most at risk of radicalisation of recruitment to Boko Haram. In addition to this the U.S provided approximately 71 million dollars, worth of equipment, logistics support, and training to the MNJTF signatory countries, to enable them to participate effectively in the $\mathrm{MNJTF}^{19}$.

\section{Conclusion and Recommendation}

MNJTF as spearhead of Africa Union's against Boko Haram threat met many challenges such as lack of coordination, trust and funding. Even when Boko Haram's already become regional's threat, the member states mostly find itself unable to fulfill their role due to internal constraint that they have.

Africa Union able to solve this coordination problem with brokering and funneling fund and other support that they can get from international community. As the result, MNJTF able to deploy at maximum capacity, getting intelligence assistance from United States, adn deliver victory against Boko Haram's armed militant, also doing humanitarian rescue.

The recomendation that can be given is Africa Union has to solve dispute between member states through Peace and Security Council (PSC) before conducting joint task force, including implementing resolution that has to be implemented by all of member states to increase their contribution in Peace Fund, so there would be no constraint in regards of coordination and logistic.

\footnotetext{
${ }^{18} \mathrm{Ibid}, \mathrm{pg} .21$

${ }^{19}$ Dauda Hairiya (2017), op.cit, pg. 54
} 


\section{Bibliography}

\section{Book}

Isiaka A. Badmus (2015), The Africa Union's Role in Peacekeeping : Building on Lessons Learned from Security Operations, Palgrave Macmillan, London

Joseph S. Nye, Jr, Peace in Parts : Integration and Conflict in Regional Organization (Boston, Mass.1971)

Lucky E. Asuelime and Ojechenemi J. David (2015), Boko Haram : The Socio-economic Drivers, Springer, New York

\section{Dissertation}

Dauda Hairiya (2017), The Role of the Multinational Joint Task Force in Fighting Against Boko Haram in Africa, University of Ghana

\section{Journal}

Ellysee Martin Atangana (2018), The underlying reasons for the emerging dynamic of regional security cooperation against Boko Haram, Africa Review, Routledge

Isaac Olawale Albert (2017), Rethinking the Functionality of the Multinational Joint Task Force in Managing the Boko Haram Crisis in the Lake Chad Basin, Africa Development, Senegal

Jacob Zenn, Atta Barkindo, and Nicholas A Heras (2013), The Ideological Evolution of Boko Haram in Nigeria, The Rusi Journal, United Kingdom

Usman A. Tar and Adejoh Sunday (2017), Military Alliance and Counter-Terrorism in Sub-Saharan Africa : The Multi-National Joint Task Force in Perspective, Covenant University Journal of Politics and International Affair

William Assanvo, Jeannine Ella A Abatan and Wendyam Aristide Sawago (2016), Assesing the Multinational Joint Task Force Against Boko Haram, Institute for Security Studies, Cape Town 